\title{
Pittosporum peridoticola (Pittosporaceae), a new ultramafic obligate species restricted to Kinabalu Park (Sabah, Malaysia)
}

\author{
John B. Sugau ${ }^{1}$ and Antony van der Ent ${ }^{2,3^{*}}$ (1)
}

\begin{abstract}
Background: Kinabalu Park, in Sabah (Malaysia) on Borneo Island, is renowned for the exceptionally high plant diversity it protects, with at least 5000 plant species enumerated to date. Discoveries of plant novelties continue to be made in Sabah, especially on isolated ultramafic outcrops, including in the genus Pittosporum (Pittosporaceae) with P. linearifolium from Bukit Hampuan on the southern border of the Park, and P. silamense from Bukit Silam in Eastern Sabah, both narrow endemics restricted to ultramafic soils.

Results: A distinctive new species of Pittosporum (P. peridoticola J.B.Sugau and Ent, sp. nov.) was discovered on Mount Tambuyukon in the north of Kinabalu Park during ecological fieldwork. The diagnostic morphological characters of this taxon are discussed and information about the habitat in which it grows is provided. The soil chemistry in the rooting zone of $P$. peridoticola has high magnesium to calcium quotients, high extractable nickel and manganese concentrations, but low potassium and phosphorus concentrations, as is typical for ultramafic soils. Analysis of foliar samples of various Pittosporum-species originating from ultramafic and non-ultramafic soils showed a comparable foliar elemental stoichiometry that is suggestive of 'Excluder-type' ecophysiology.
\end{abstract}

Conclusion: Pittosporum peridoticola is an ultramafic obligate species restricted to Kinabalu Park with only two known populations within the boundaries of the protected area. It is vulnerable to any future stochastic landscape disturbance events, such as forest fires or severe droughts, and therefore its conservation status is 'Near Threatened'.

Keywords: Hyper-endemic, Mount Tambuyukon, Soil chemistry, Ultramafic obligate

\section{Background}

Kinabalu Park, in the northwestern part of the Malaysian state of Sabah (on Borneo Island), is renowned for the exceptionally high plant diversity it harbours, with over 5000 plant species enumerated from an area less than $1200 \mathrm{~km}^{2}$ (Beaman 2005; Van der Ent et al. 2015a). Ultramafic outcrops (also called 'serpentine' or 'ultrabasic') are known globally for hosting distinctive and highly endemic floras (Brooks 1987). Ultramafic soils

\footnotetext{
*Correspondence: a.vanderent@uq.edu.au

${ }^{3}$ Centre for Mined Land Rehabilitation, Sustainable Minerals Institute,

The University of Queensland, Brisbane, QLD 4072, Australia

Full list of author information is available at the end of the article
}

are characterised by unusual chemical characteristics, including high concentrations of potentially phytotoxic elements (nickel, cobalt, chromium), low concentrations of essential plant nutrients, and cation imbalances (high magnesium to calcium quotients) (Proctor 2003).

Ultramafic outcrops are widespread in Sabah, and occur in Kinabalu Park, predominantly on Mount Tambuyukon, and on the southern slope of Mount Kinabalu (Van der Ent et al. 2015a). In Kinabalu Park, ultramafic soils are known for high levels of species-richness and (local) endemism (Beaman and Beaman 1990). Overall, the vegetation on ultramafic soils often has a relative shorter stature and more open aspect, compared to vegetation on non-ultramafic soils. On tropical isolated

\section{楚 Springer}


mountains the altitudinal vegetation zonation is often compressed (Proctor et al. 1988; Bruijnzeel et al. 1993). This effect is particularly apparent on Mount Tambuyukon $(2579 \mathrm{~m}$ asl), where the vegetation on the summit ridge is a graminoid dwarf scrub. Such dwarf scrub also occurs locally on the Mount Kinabalu massif, such as at Marai Parai, Bukit Babi and the Mentaki Ridge (Van der Ent et al. 2015a). At similar elevations on soils derived from granite or sandstone geology, relatively tall forest occurs. As part of ecological fieldwork undertaken in 2010-2013 a distinctive Pittosporum was found on the main summit ridge of Mount Tambuyukon, which is described here.

\section{Methods}

In this article we use the Biological Species Concept (BSC), which is based on considering discontinuities in morphological variation as an indirect assessment of reproductive isolation and lack of gene flow preventing lineages from homogenising (Coyne and Orr 2004; Mallet 2008). Dried plant specimens were examined from the Sabah Parks Herbarium (SNP). Soil samples $(\mathrm{n}=9)$ were collected near individuals of $P$. peridoticola on the summit ridge of Mount Tambuyukon, air-dried at room temperature and digested with concentrated nitric and hydrochloric acid in a specialized microwave (Milestone Start D). Foliar samples of $P$. ferrugineum $(\mathrm{n}=1)$, P. linearifolium $(\mathrm{n}=3)$, P. longisepalum $(\mathrm{n}=1)$, P. resiniferum $(\mathrm{n}=1)$, P. peridoticola $(\mathrm{n}=1)$ were collected in Kinabalu Park and the nearby Bukit Hampuan Forest Reserve, airdried at room temperature and similarly digested with concentrated nitric acid and hydrogen peroxide in a specialized microwave. Both soil and leaf sample digest solutions were then measured with an ICP-AES (Varian Vista Pro II) for nickel, cobalt, manganese, iron, magnesium, calcium, sodium, potassium and phosphorus. The ICPAES instrument was calibrated using a 6-point multi-element standard prepared in each solution.

\section{Results \\ Distribution and ecology of the genus Pittosporum in Sabah}

The family Pittosporaceae consists of nine genera, of which the genus Pittosporum is the sole representative in Sabah (Malaysia, on the island of Borneo). The genus (approximately 200 species) ranges from tropical areas in Africa, South and East Asia and Australasia to the Pacific Region. All Pittosporum taxa are trees and woody shrubs growing to $2-30 \mathrm{~m}$ tall. In Sabah a total of six species have been described to date (Sugau 1994; 1995): Pittosporum ferrugineum Aiton, P. linearifolium Sugau, $P$. longisepalum Bakker, P. ramiflorum Zollinger ex. Miquel, $P$. resiniferum Hemsley and $P$. silamense Sugau. Of these
P. ferrugineum is relatively widespread in Sabah, whereas $P$. ramiflorum, $P$. resiniferum and $P$. longisepalum are principally known from Kinabalu Park in Sabah, but also occur elsewhere in Southeast Asia. Two species, P. linearifolium and $P$. silamense, are hyper-endemics restricted to isolated ultramafic outcrops in Sabah on Bukit Hampuan and Bukit Silam respectively (Sugau 1994).

\section{Species description}

Pittosporum peridoticola J.B.Sugau and Ent, sp. nov. (Figures 1 and 2).

The new species is morphologically similar to $P$. longisepalum Bakker in having finely impressed veins on the upper leaf surface and slightly recurved margin when dry but differs by its smaller obovate leaves, absent or very short (to $3 \mathrm{~mm}$ long) grooved petioles, shorter sepals (less than $5 \mathrm{~mm}$ long), longer staminal filaments $(5 \mathrm{~mm}$ long), style (c. $2.5 \mathrm{~mm})$ and petals $(6-16 \mathrm{~mm}$ long). Pittosporum longisepalum has larger (4-6 long, 1.5-2 cm wide) elliptic leaves, longer (up to $5 \mathrm{~mm}$ long) sub-terete petioles, longer sepals (c. $7 \mathrm{~mm}$ long), shorter staminal filaments (c. $3 \mathrm{~mm}$ long), style (c. $1.5 \mathrm{~mm}$ long) and petals (c. $8 \mathrm{~mm}$ long). A comparison of taxonomical characters between $P$. longisepalum and $P$. peridoticola is provided in Table 1.

Type-A. van der Ent et al. SNP 25748, Malaysia. Sabah. Kinabalu Park, Mount Tambuyukon, 14 April 2011 (holotype SNP; isotype SAN).

Shrub, 1.5-2 m tall, multi-branched, stem barely $4-5 \mathrm{~cm}$ thick at base. Young parts hairy. Leaves spirally arranged, borne on distal $15-20 \mathrm{~cm}$ of the branches, light green, obovate, $2-4.5 \times 0.8-2 \mathrm{~cm}$, coriaceous, brown to dark brown on both sides when dry, hairy (when young), glabrous when mature; apex acute to shortly cuspidate, base cuneate and typically decurrent (to the base of petiole), margin entire, slightly recurved when dry, midrib sunken on upper surface of lamina, raised on lower surface, secondary veins 4-6 pairs, not very conspicuous, finely impressed on upper leaf surface. Petiole absent or very short, to c. $3 \mathrm{~mm}$ long, grooved. Inflorescence terminal, a simple thyrse, with up to eight flowers. Peduncle 1-2.5 cm long, hairy, pedicel hairy. Flowers with sepals, petals and stamens 5-merous; sepals lanceolate, 3-4 $\mathrm{mm}$ long, hairy; petals oblong, 6-16 $\times 2 \mathrm{~mm}$, white; stamens c. $6 \mathrm{~mm}$ long, filaments $5 \mathrm{~mm}$ long, anthers oblong, c. $1.5 \mathrm{~mm}$ long, apiculate; ovary ellipsoid, c. $3 \mathrm{~mm}$ long, densely hairy; style c. $2.5 \mathrm{~mm}$; stigma capitate. Fruit not seen.

\section{Additional specimen examined}

Malaysia. Borneo, Sabah. Kinabalu Park. SNP 27094Mentaki Ridge; SNP 26812 and SNP 26781-Mount Tambuyukon, Musang Camp to Summit ridge; SNP 


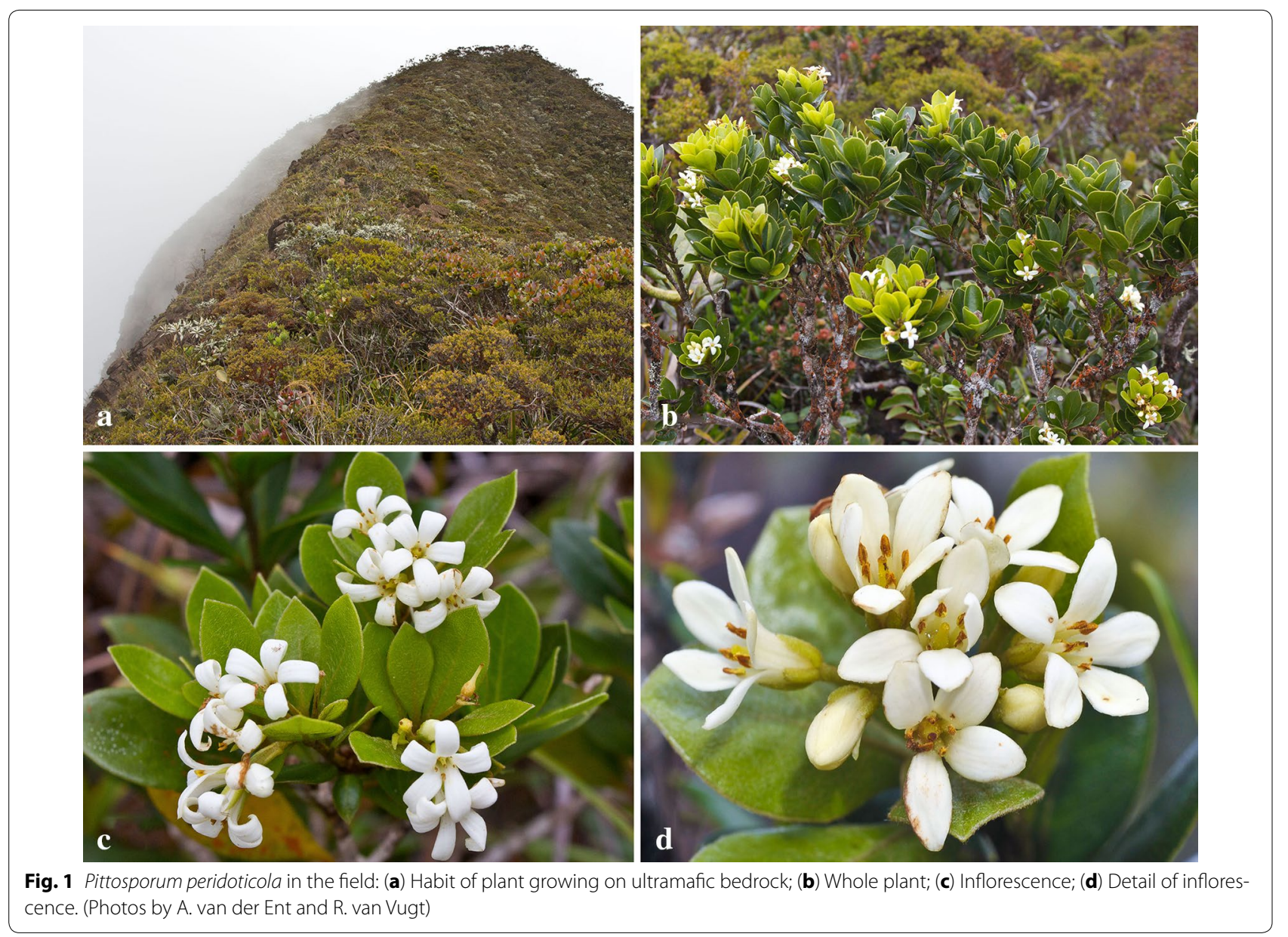

2574-Tambuyukon ridge second peak; SNP 30597. Specimens were all flowering and collected by Van der Ent et al.

\section{Distribution and habitat}

Pittosporum peridoticola is found exclusively in ligneous scrub on extreme ultramafic soil on Mount Tambuyukon and Mount Kinabalu. The sites where it occurs are located at $1700-2500 \mathrm{~m}$ asl in dense vegetation consisting of shrubs (1-2 $\mathrm{m}$ tall). Co-occurring species include: Styphelia malayanus Jack subsp. malayanus (Ericaceae), Phyllocladus hypophyllus Hook. f. (Phyllocladaceae), Weinmannia clemensiae Steenis (Cunoniaceae), Leptospermum javanicum Blume (Myrtaceae), Wikstroemia indica (L.) C.A.Mey. (Thymelaeaceae), Lithocarpus rigidus Soepadmo (Fagaceae), Podocarpus brevifolius (Stapf) Foxw. and Dacrydium gibbsiae Stapf (Podocarpaceae). On the summit ridge of Mount Tambuyukon, Pittosporum peridoticola was found in an area of just a few hundred $\mathrm{m}^{2}$ and only a small number of individuals were seen. Similarly, the habitat on Mount Kinabalu (Mentaki Ridge) is very small, comprising of only a few individuals.
Other rare regional species are also known only from populations on ultramafic soils in Kinabalu Park, for example Drosera ultramafica A.Fleischm., A.S.Rob. and S.McPherson (Droseraceae), Nepenthes rajah Hook.f. (Nepenthaceae), Calanthe otuhanica C.L.Chan and T.J.Barkman (Orchidaceae) and Weinmannia clemensiae Steenis (Cunoniaceae).

\section{Etymology}

The specific epithet "peridoticola" denotes the peridotite (ultramafic) bedrock on which this species grows on Mount Tambuyukon and Mount Kinabalu (from 'peridotite' the ultramafic bedrock, and; cola (Latin)-to dwell or inhabit). Peridotite is a dense, coarse-grained igneous rock, consisting of olivine and pyroxene minerals (magnesium-iron-silicates). This rock-type, to varying degrees serpentinised, is the main bedrock of ultramafic outcrops in Sabah, and forms the Mount Tambuyukon massif.

Key to Pittosporum species in Sabah and Sarawak (vegetative characters):

$1 a$. Leaves very narrowly elliptic to linear, mostly $0.5-$ $1.1 \mathrm{~cm}$ wide $P$. linearifolium. 


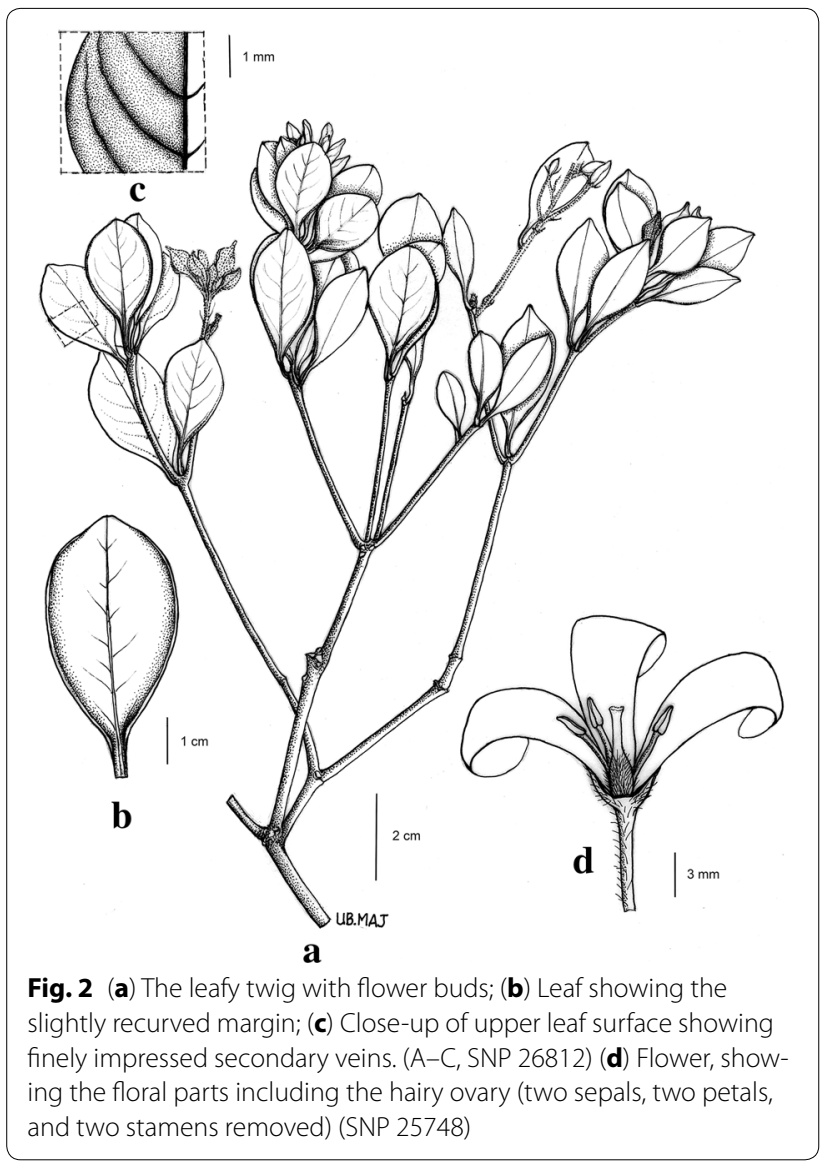

1b. Leaves elliptic to obovate, typically wider (more than $1.5 \mathrm{~cm}$ wide ..2.

$2 a$. Leaves persistently densely hairy on the lower side, and conspicuously bullate between the veins on the upper side; margins markedly recurved when dry ............. silamense.

$2 b$. Leaves never persistently hairy (glabrous or, if hairy, only when very young), and not bullate or veins only finely impressed on the upper side; margins not recurved or slightly recurved when dry ...3.

$3 a$. Veins on the upper leaf surface finely impressed; margin slightly recurved . . .4 .

$3 b$. Veins on the upper leaf surface flat, not impressed; margin not recurved 5.

$4 a$. Leaves elliptic; petiole c. $5 \mathrm{~mm}$ long, sub-terete; sepals 6-7 $\mathrm{mm}$ long in flower P. longisepalum.

$4 b$. Leaves obovate; petiole very short to c. $3 \mathrm{~mm}$ long, grooved; sepals less than $5 \mathrm{~mm}$ ..P. peridoticola.

$5 a$. Leaves elliptic, or if oblanceolate to obovate then the apex gradually acuminate. Inflorescences borne in the leafy portions of branches .P. ferrugineum.

$5 b$. Leaves markedly obovate, the apex abruptly cuspidate. Inflorescences borne on bare branches .... 6.

$6 a$. Petioles 8-18 $\mathrm{mm}$ long. Flower larger, the petals 9-12 mm long. Infructescence peduncle not conspicuous or up to $0.5 \mathrm{~cm}$ long only. Mature fruits $1.7-2 \mathrm{~cm}$ long ............. resiniferum.

6b. Petioles longer, $15-25 \mathrm{~mm}$ long. Flower smaller, the petals only 4-7 mm long. Infructescence peduncle longer,

Table 1 Comparison of taxonomical characters between Pittosporum longisepalum and P. peridoticola

\begin{tabular}{lll}
\hline Character & P. longisepalum & P. peridoticola \\
\hline Leaf size $(\mathrm{cm})$ & $4-6 \times 1.5-2$ & $2-4 \times 0.8-2$ \\
Leaf shape & Elliptic & Obovate \\
Leaf apex & Acute to acuminate & Rounded, acute to shortly cuspidate \\
Leaf base & Cuneate, decurrent & Cuneate, decurrent \\
Leafhairiness & Slightly pubescent beneath & Glabrescent, glabrous when mature \\
Veins in upper surface & Secondary veins slightly impressed & Secondary veins slightly impressed \\
Number of veins & $5-7$ pairs & $4-6$ pairs \\
Flowering habit & Among leaves & Among leaves \\
Petal length $(\mathrm{mm})$ & $\sim 8$ & $6-16 \mathrm{~mm}$ \\
Ovary & Hairy & Hairy \\
Sepal length $(\mathrm{mm})$ & $\sim 7$ & $3-4$ mm \\
Pedunclelength $(\mathrm{cm})+$ hairiness & $2-3 ;$ hairy & $1-2.5 ;$ hairy \\
Leafmargin & Entire; recurved & Entire; slightly recurved \\
Petiole $(\mathrm{mm})$ & $\sim 5$ & Very short to c. 3 \\
Filament length $(\mathrm{mm})$ & $\sim 3$ & 5 mm \\
Anther & Oblong; apiculate & Oblong; apiculate \\
Style & $\sim 1.5 \mathrm{~mm}$ & $2.5 \mathrm{~mm}$ \\
Stigma & Capitate & Capitate \\
\hline
\end{tabular}


1-3 cm long. Mature fruits $1-1.5 \mathrm{~cm}$ long

P. ramiflorum.

\section{Soil and foliar chemistry}

The analysis of a soil sample collected between the roots of $P$. peridoticola, and foliar analysis of different Pittosporum spp. are presented in Table 2. The results show that the soil chemistry from the rooting zone of $P$. peridoticola is extreme in containing very high magnesium $(\mathrm{Mg})$, nickel $(\mathrm{Ni})$ and manganese $(\mathrm{Mn})$, but relatively low calcium $(\mathrm{Ca})$ and potassium $(\mathrm{K})$ concentrations. This chemistry is characteristic for ultramafic soils, and the soils on which it occurs are 'hypermagnesian soils' (Hypermagnesic Cambisols) (Van der Ent and Wood 2012). These soils occur at high elevation (1700-2500 m asl.), are very shallow and skeletal and derive from primary weathering of the bedrock close to the surface. They have high Mg:Ca quotients, low $\mathrm{CEC}$, high extractable $\mathrm{Ni}$ and $\mathrm{Mn}$ concentrations, and are moderately acidic. Total soil $\mathrm{K}$ and $\mathrm{P}$ concentrations are low 52 and $118 \mu \mathrm{g} \mathrm{g}^{-1}$ respectively. As such these soil properties might induce phytotoxicity and nutrient deficiencies, and $P$. peridoticola must have evolved adaptations to these adverse soil chemical conditions.

The foliar analyses show that Pittosporum spp. are effective at excluding potentially phytotoxic elements $(\mathrm{Ni}, \mathrm{Mn}, \mathrm{Mg}$ ) from the shoot and at the same time are efficient in sequestering essential elements $(\mathrm{Ca}, \mathrm{K}, \mathrm{Na}$, P). Foliar accumulation of most elements is rather similar between the Pittosporum spp. despite the fact they grew in different habitats and on different soils. The leaf samples from $P$. ferrugineum, $P$. longisepalum and $P$. resiniferum originate from non-ultramafic soils, and these soils generally have higher concentrations of $\mathrm{Ca}$, $\mathrm{K}$ and $\mathrm{P}$ compared to ultramafic soils. Nevertheless, the concentrations of foliar elements are either similar or erratic compared to Pittosporum spp. from ultramafic soils, and this points towards 'Excluder-type' ecophysiology (sensu Baker 1981) of this genus on a wide range of soil types.

\section{Discussion and conclusion}

\section{Ecological and evolutionary aspects}

Ultramafic outcrops may be conceptualized as 'edaphic islands' (Kruckeberg 1991; Rajakaruna 2004), and as such these insular features in the landscape can confer genetic isolation, which in association with locally strong climactic and edaphic stresses, may promote plant speciation and endemism (Kruckeberg 1986; Wong 2011; Rajakaruna and Boyd 2008). The combination of isolated ultramafic soils in combination with (high) elevation has been shown to be particularly conductive for the evolution of local endemics ('neo-endemics') on Mount Kinabalu, for example in the genera Dendrochilum (Orchidaceae), Elatostema (Urticaceae), Rhododendron (Ericaceae), Leptospermum (Myrtaceae), and Nepenthes (Nepenthaceae) (Barkman and Simpson 2001; Argent et al. 2007; Beaman 2001; Lee and Lowry 1980; Van der Ent et al. 2015b). Neo-endemic species are thought to have evolved in situ from related precursor taxa, and often form high-elevation and lower-elevation speciespairs. Other species are paleo-endemics, that were formerly widespread, but continue to persist locally when competition pressure is low (Stebbins and Major 1965; Anacker 2014).

The new species $P$. peridoticola is the third narrowly endemic species in the genus in Sabah that is obligate (restricted) to ultramafic soils (together with P. linearifolium and P. silamense). All three species are each known from isolated mountain summits (Mount Tambuyukon/Mentaki Ridge, Bukit Hampuan and Bukit Silam respectively). The habitat of all three species is very open forest or dwarf scrub. This suggests a high light requirement permitted through competitive exclusion due to habitat specialisation under strong edaphic stresses. Pittosporum peridoticola in particular appears to have a slow growth rate, judging from the thick woody gnarled stems, and co-occurs with a number of other plant species endemic to Mount Tambuyukon, such as Eriobotrya balgooyi K.M.Wong and Ent (Rosaceae) (Wong and Van der Ent 2014), Gynura tambuyukonensis Vanij. and Ent (Asteraceae) (Van der Ent and Vanijajiva (Van

Table 2 Foliar and soil chemistry of Pittosporum species (mean values in $\boldsymbol{\mu g ~ g}^{-\mathbf{1}}$ )

\begin{tabular}{|c|c|c|c|c|c|c|c|c|c|c|c|}
\hline Species & Al & $\mathrm{Ca}$ & Co & $\mathrm{Cr}$ & $\mathrm{Fe}$ & $\mathrm{K}$ & $\mathrm{Mg}$ & $M n$ & $\mathrm{Na}$ & $\mathrm{Ni}$ & $\mathbf{P}$ \\
\hline P. ferrugineum $(n=1)$ & 38 & 12,145 & 1.8 & 2.5 & 22 & 2080 & 1650 & 1080 & 10,330 & 3.3 & 275 \\
\hline P. linearifolium $(n=3)$ & 34 & 8860 & 5 & 4 & 43 & 4690 & 4420 & 334 & 3790 & 8 & 484 \\
\hline P. longisepalum $(\mathrm{n}=1)$ & 26 & 18,730 & 1.1 & 1.6 & 31 & 8825 & 2540 & 1095 & 6600 & 10 & 443 \\
\hline P. resiniferum $(n=1)$ & 34 & 29,080 & 0.7 & 1.8 & 18 & 4900 & 8710 & 381 & 67 & 3.4 & 422 \\
\hline P. peridoticola $(n=1)$ & 27 & 12,480 & 16 & 0.7 & 18 & 6955 & 7200 & 195 & 1329 & 13 & 335 \\
\hline Soil P. peridoticola $(n=9)$ & 4800 & 674 & 284 & 1293 & 169,500 & 52 & 25,420 & 5070 & 55 & 1571 & 118 \\
\hline
\end{tabular}

The soil is from the habitat of Pittosporum peridoticola on Mount Tambuyukon 
der Ent and Vanijajiva 2014), Rhododendron meijeri Argent, A.L.Lamb and Phillipps and R. baconii Argent, A.L.Lamb and Phillipps (Ericaceae) (Argent et al. 2007). Other hyper-endemic species from Mount Tambuyukon include the recently described Begonia moneta C.-I Peng, Rimi and C. W. Lin and B. peridoticola Rimi, C.-I Peng and C. W. Lin (Begoniaceae) (Peng et al. 2015). The situation of ultramafic obligate Pittosporum-species in Sabah mirror that of an another genus of woody shrubs, Timonius (Rubiaceae), of which four species are currently understood as ultramafic obligates: T. tambuyukonensis J.Chen, T. stenolobus J.Chen and K.M.Wong, T. leopoldii J.Chen and K.M.Wong and T. ophioliticus J.Chen, with the first three species probably endemic to Kinabalu Park (Chen et al. 2014). Future molecular studies might elucidate the phylogenetic position of the ultramafic obligate Pittosporum-species in Sabah.

\section{Conservation status}

The habitat of $P$. peridoticola lies entirely in Kinabalu Park (an IUCN Category II National Park) and it is therefore statutorily protected. Nevertheless the restriction of this species to just two known populations on Mount Tambuyukon and Mount Kinabalu respectively, and the inherent small total number of individuals means that this species is vulnerable to any future stochastic events, such as forest fires or severe droughts that could ultimately lead to the extinction of this rare taxon. However, as there is no currently available evidence of decline or fluctuations in the extent of its occurrence (EOO), the area of occurrence (AOO), or the number of mature individuals, the conservation status of the species is currently classified as 'Near Threatened' (IUCN 2001).

\section{Authors' contributions}

AVDE conducted the fieldwork and collected the plant specimens in Kinabalu Park. JBS carried out the taxonomical study. AVDE undertook the laboratory analyses. JBS and AVDE prepared the manuscript. Both authors read and approved the final manuscript.

\section{Author details \\ 1 Sabah Forestry Department, Forest Research Centre, Jalan Sepilok, Sepilok, 90175 Sandakan, Sabah, Malaysia. ${ }^{2}$ Laboratoire Sols et Environnement, Uni- versité de Lorraine-INRA, UMR 1120, Nancy, France. ${ }^{3}$ Centre for Mined Land Rehabilitation, Sustainable Minerals Institute, The University of Queensland, Brisbane, QLD 4072, Australia.}

\section{Acknowledgements}

We would like to express our gratitude to Sabah Parks for the collaborative research project during which this species was discovered, and in particular thank Rimi Repin, Sukaibin Sumail and Rositti Karim (Sabah Parks) and Postar Miun (Sabah Forestry Department). The Director of the Sabah Parks Herbarium (SNP) is gratefully acknowledged for the loan of the herbarium material. We thank Ubaldus Majawal of the Forest Research Centre, Sabah Forestry Department for the illustration of P. peridoticola. Finally we thank an anonymous reviewer for constructive comments that improved the manuscript during revision.

\section{Competing interests}

The authors declare that they have no competing interests.

Received: 28 September 2015 Accepted: 14 January 2016

Published online: 01 February 2016

\section{References}

Anacker BL (2014) The nature of serpentine endemism. Am J Bot 01(2):219_ 224. doi:10.3732/ajb.1300349

Argent G, Lamb A, Phillipps A (2007) The Rhododendrons of Sabah, Malaysian Borneo. Natural History Publications (Borneo) and Royal Botanic Garden, Edinburgh

Baker AJM (1981) Accumulators and excluders-strategies in the response of plants to heavy metals. J Plant Nutr 3(1-4):643-654. doi:10.1080/01904168109362867

Barkman TJ, Simpson BB (2001) Origin of high-elevation Dendrochilum species (Orchidaceae) endemic to Mount Kinabalu, Sabah, Malaysia. Syst Botany 26: 658-669. http://www.jstor.org/stable/3093987

Beaman RS (2001) Phylogeny and biogeography of Elatostema (Urticaceae) from Mount Kinabalu. Sabah Parks Nature J 4:71-93

Beaman JH (2005) Mount Kinabalu: hotspot of plant diversity in Borneo. Biologiske Skrifter 55:103-127

Beaman JH, Beaman RS (1990) Diversity and distribution patterns in the flora of Mount Kinabalu. In: Kalkman K, Geesink R (eds) Baas, P. The plant diversity of Malesia, Kluwer Academic Publishers, pp 147-160

Brooks RR (1987) Serpentine and its vegetation: a multidisciplinary approach, Dioscorides Press

Bruijnzeel L, Waterloo M, Proctor J, Kuiters A, Kotterink B (1993) Hydrological observations in montane rain forests on Gunung Silam, Sabah, Malaysia with special reference to the "Massenerhebung" effect. J Ecol 81(1):145167. doi: $10.2307 / 2261231$

Chen J, Wong KM, Van der Ent A, Tan HTW (2014) Nine new species of Timonius (Rubiaceae) from Kinabalu Park. Borneo. Phytotaxa 181(3):138-150. doi:10.11646/phytotaxa.181.3.2

Coyne JA, Orr HA (2004) Speciation. Sinauer Associates, Sunderland, Massachusetts, p 545

IUCN (2001) IUCN Red List Categories and Criteria. Accessed 31 Aug 2014: http://www.iucnredlist.org/static/categories_criteria_3_1

Kruckeberg AR (1986) An essay: the stimulus of unusual geologies for plant speciation. Syst Botany 11:455-463. doi:10.2307/2419082

Kruckeberg AR (1991) An essay: geoedaphics and island biogeography for vascular plants. Aliso 13(1):225-238

Lee DW, Lowry JB (1980) Plant speciation on tropical mountains: Leptospermum (Myrtaceae) on Mount Kinabalu. Borneo. Bot J Linn Soc 80(3):223242. doi:10.1111/j.1095-8339.1980.tb01987.x

Mallet J (2008) Hybridization, ecological races and the nature of species: empirical evidence for the ease of speciation. Philos Trans R Soc Lond B Biol Sci 363:2971-2986. doi:10.1098/rstb.2008.0081

Peng Cl, Lin CW, Rimi R, Kono Y, Leong W, Chung KF (2015) Two new species of Begonia, B. moneta and B. peridoticola (Begoniaceae) from Sabah, Malaysia. Bot Stud 56:e7. doi:10.1186/s40529-015-0087-5

Proctor J (2003) Vegetation and soil and plant chemistry on ultramafic rocks in the tropical Far East. Perspect Plant Ecol Evol Syst 6(1-2):105-124. doi:10.1078/1433-8319-00045

Proctor J, Phillipps C, Duff G, Heaney A, Robertson F (1988) Ecological studies on Gunung Silam, a small ultrabasic mountain in Sabah, Malaysia. I. Environment, forest structure and floristics. J Ecol 76(2):320-340. doi:10.2307/2260596

Rajakaruna N (2004) The edaphic factor in the origin of plant species. Int Geol Rev 46(5):471-478. doi:10.2747/0020-6814.46.5.471

Rajakaruna N, Boyd RS (2008) Edaphic factor. Encyclopedia Ecol 46:471-478

Stebbins GL, Major J (1965) Endemism and speciation in the California flora. Ecol Monogr 35:1-35. doi:10.2307/1942216

Sugau JB (1994) Two new species of Pittosporum (Pittosporaceae) from Borneo. Sandakania 4:41-45

Sugau JB (1995) Chapter 23. Pittosporaceae. In: Tree Flora of Sabah and Sarawak, Volume One. Soepadmo, E and Wong, K.M. (editors). Forest 
Research Institute (FRIM), Sabah Forestry Department and Sarawak Forestry Department

Van der Ent A, Vanijajiva O (2014) Gynura tambuyukonensis (Asteraceae), an obligate ultramafic species endemic to Mount Tambuyukon (Kinabalu Park, Sabah, Malaysia). Phytotaxa 158(3):291-296. doi:10.11646/ phytotaxa.158.3.9

Van der Ent A, Wood JJ (2012) Mount Tambuyukon —an intriguing mountain and its orchids. Males Orchid J 10:102-122

Van der Ent A, Wong KM, Sugau J, Repin R (2015a) Plant diversity of ultramafic outcrops in Sabah (Malaysia). Aust J Bot 63:204-215. doi:10.1071/BT14214

Van der Ent A, Sumail S, Clarke C (2015b) Habitat differentiation of obligate ultramafic Nepenthes endemic to Mount Kinabalu and Mount Tambuyukon (Sabah, Malaysia). Plant Ecol 216:789-807. doi:10.1007/ s11258-015-0468-6
Wong KM (2011) A biogeographic history of Southeast Asian rainforests. Chapter 2. In: Wickneswari R., Cannon C. (eds) Managing the Future of Southeast Asia's Valuable Tropical Rainforests: A Practitioner's Guide to Forest Genetics: Heidelberg, Springer Science + Business Media B.V. pp $21-55$

Wong KM, Van der Ent A (2014) Eriobotrya balgooyi (Rosaceae), a new obligate ultramafic endemic from Kinabalu Park. Borneo Plant Ecol Evol 147(1):134-140. doi:10.5091/plecevo.2014.938

\section{Submit your manuscript to a SpringerOpen ${ }^{\circ}$ journal and benefit from:}

- Convenient online submission

- Rigorous peer review

- Immediate publication on acceptance

- Open access: articles freely available online

- High visibility within the field

- Retaining the copyright to your article

Submit your next manuscript at $\boldsymbol{~ s p r i n g e r o p e n . c o m ~}$ 